\title{
Ecotourism positively affects awareness and attitudes but not conservation behaviours: a case study at Grande Riviere, Trinidad
}

\author{
Kerry A. Waylen, Philip J.K. McGowan, Pawi Study Group and \\ E. J. MILNER-GULLAND
}

\begin{abstract}
Ecotourism is often suggested as a tool for promoting conservation but evidence for its usefulness is mixed. The success of conservation projects is widely recognized to depend upon the positive attitudes of local communities and thus it is important to know if ecotourism affects local perceptions of natural resources and conservation, as these can be important determinants of conservation behaviour. Rapid Rural Appraisal and questionnaire-based interviews were used to investigate this issue in the village of Grande Riviere, Trinidad. This has a community-based ecotourism programme for leatherback turtles Dermochelys coriacea, and is also one of the few sites where the Critically Endangered endemic Trinidad piping-guan Pipile pipile may be sighted. Topics addressed were knowledge and awareness of local conservation issues, focusing on attitudes to the environment in general, turtles and the Trinidad piping-guan. Ecotourism significantly affected perceptions. Villagers showed more awareness and support for turtle conservation than for the piping-guan or any other wildlife. Moreover, those households directly benefiting from the ecotourism industry had better knowledge of local natural resources and greater general awareness of conservation issues (not limited to turtles). Other socio-economic factors such as education and income also affected attitudes and knowledge but the ecotourism effect was still present after accounting for these. Hunting was seen as the main threat to wildlife but was also a popular pastime, illustrating the potential for mismatch between attitudes and conservation behaviours.
\end{abstract}

Keywords Attitudes, behaviour, community conservation, Dermochelys coriacea, ecotourism, Galliformes, Pipile pipile, Trinidad.

Kerry A. WAylen* (Corresponding author) and E.J. Milner-Gulland Centre for Environmental Policy \& Division of Biology, Imperial College London, Silwood Park Campus, Ascot, SL5 7PY, Berkshire, UK. E-mail kerry.waylen04@imperial.ac.uk

Philip J.K. McGowan World Pheasant Association, Newcastle University Biology Field Station, Heddon on the Wall, UK.

Pawi Study Group c/o A. Hailey, Department of Life Sciences, The University of the West Indies, Trinidad and Tobago.

*Also at: Macaulay Institute, Craigiebuckler, Aberdeen, AB15 8QH, UK.

Received 9 January 2008. Revision requested 24 January 2008.

Accepted 7 April 2008.

\section{Introduction}

A popular approach to conservation is the development A of nature tourism enterprises or ecotourism. Ecotourism is defined by the International Ecotourism Society as 'responsible travel to natural areas that conserves the environment and sustains the well-being of local people' (Wood, 2002). Tourism can bring significant financial benefits to areas supporting charismatic wildlife (Walpole \& Leader-Williams, 2002; Adams \& Infield, 2003; Lorimer, 2009) and thus can be a relatively cheap method of facilitating both development and conservation (Cater \& Goodall, 1997; UNWTO, 2006). The market is lucrative and can be an important source of income for developing countries. In 2004 global ecotourism grew three times faster than the tourism industry as a whole, which itself is growing at about $10 \%$ per year (The International Ecotourism Society, 2005).

However, evidence suggests that ecotourism is not a universal panacea for conservation problems (Weaver, 1998; Kruger, 2005). Although it sometimes benefits both people and threatened species, it is likely that many ecotourism projects fail to achieve their aims for either conservation (Yu et al., 1997) or development (Bookbinder et al., 1998). However, as other forms of community-based conservation have also had limited success (Adams et al., 2004), we need to have a better understanding of the impacts of ecotourism because there are no easy alternatives. One way in which tourism could prove its worth is in improving local awareness and attitudes to conservation.

All community-based conservation initiatives assume that positive financial or livelihood gains, together with improved participation, will act as an incentive to promote positive attitudes towards conservation (Spiteri \& Nepal, 2006). For example, local people's attitudes to Serengeti National Park were worsened by perceived costs from the Park but improved by participation in a community-based project (Kideghesho et al., 2007). Education programmes are also thought to influence attitudes, although this effect is not always observed (Brossard et al., 2005). In ecotourism projects the income from visiting tourists provides the incentive and, in addition, it is sometimes assumed that ecotourism, as with other community-based conservation operations, will result in a change in local awareness and attitudes (Sekercioglu, 2002).

Existing evidence does not clearly support these assumed effects on attitudes or awareness, and further 
research is required. For example, a study of tourism at Laikipia, Kenya, found that local people receiving benefits from tourism tend to have an increased appreciation for wildlife (Gadd, 2005). However, other studies have found tourism does not foster support for conservation, even though local people may be positive about the tourism itself (Mehta \& Kellert, 1998; Walpole \& Goodwin, 2001) and be aware of the link between tourism and conservation (Walpole \& Goodwin, 2001).

Creating positive attitudes to conservation is likely to be especially important when other mechanisms for changing behaviour, such as regulation, are ineffective or inappropriate. Increasing awareness is often considered a prerequisite or an equal aim to changing attitudes (Maibach, 1993) and can predict some conservation behaviours (Beedell \& Rehman, 2000). However, conservationists have tended to assume a simple relationship between awareness or attitudes and their effect on behaviour.

Although most psychologists agree that awareness and attitudes can be important predictors of behaviour in combination with other factors (Ajzen, 2005), it cannot be assumed that a change in these will automatically result in changing conservation behaviours. Attitudes are influenced by pre-existing values (Schultz, 2001) and by issues and processes that are not obvious to outsiders (Allendorf et al., 2006), and thus identifying the attitudes most relevant to conservation outcomes is not straightforward (Saunders et al., 2006). This complexity is apparent in Holmes' (2003) study of people local to Katavi National Park, western Tanzania. Individuals who perceived benefits from the Park were more likely to have positive attitudes to the Park and practice sustainable firewood extraction. However, many other expected links and predictors of attitudes were not found, and Holmes concluded that understanding attitudes to conservation, and links with behaviours, requires a clear understanding of various social, economic and cultural factors.

A review of community-based ecotourism initiatives (Kiss, 2004) also suggested that positive attitudes alone are insufficient to cause behavioural change. As the relationship between attitude change and behaviours that affect conservation outcomes is complex and poorly understood, it is prudent for any studies of attitudes to check if changes in attitudes lead to the expected behavioural changes.

This study probes the effect of ecotourism on awareness and attitudes to nature and its conservation, firstly by comparing perceptions of the Trinidad piping-guan Pipile pipile and turtles, which have been subject to different interventions for conservation, and secondly by comparing the effect of direct benefits of ecotourism on attitudes and awareness. Statements on wild meat consumption and hunting were used to check if awareness and attitudes corresponded with behaviours of conservation relevance. The effects of ecotourism on conservation awareness, attitudes and behaviour reveal its value as a tool for conservation.

\section{Study area}

The island of Trinidad is the most southerly in the Caribbean, with an ecology more similar to the adjacent South American mainland than the rest of the Caribbean. The only endemic bird is the Trinidad piping-guan, known locally as the pawi, which is categorized as Critically Endangered on the IUCN Red List (IUCN, 2008). Hunting is thought to be an important reason for its decline (Brooks, 1999) but the socio-economic context is poorly understood (James \& Hislop, 1998). The village of Grande Riviere, on the impoverished and remote north-east coast of Trinidad $\left(10.5^{\circ} \mathrm{N}, 61.5^{\circ} \mathrm{W}\right)$, is a key site for the pawi, as it is one of the few places where it can be reliably sighted (Hayes, 2002). Grande Riviere is also one of only two villages in Trinidad with a successful community-based turtle conservation programme: the leatherback turtle Dermochelys coriacea, categorized as Critically Endangered on the IUCN Red List (IUCN, 2008), nests at most beaches in the coastal areas and reaches its highest densities in Trinidad on the relatively small beach at Grande Riviere (James \& Fournillier, 1993).

Grande Riviere has the most tourist development of any village in this area. There are two small hotels next to the beach, open since 1993 and 2000, respectively, and a third constructed in 2005, and a few guest-houses in the village. By 2006, the year after this study, about 10,000 tourists a year stayed in the village (Harrison, 2007), with most coming to see the turtles. Although being a tour guide directly brings an individual only low and irregular financial benefits (Onwuka, 2004), this operation indirectly supports many other livelihoods. Eighty people, $25 \%$ of the village population, have some form of employment in tourism, in jobs such as hotel housekeeping and taxi driving (Harrison, 2007). Other important occupations include work on the roads, participation in unemployment relief programmes and work in agriculture. Most of the population has had a primary school education but further participation in education is limited by poor access to urban areas (CREP, 2002).

Until 1989 the slaughter of turtles on the north-east coast was a common occurrence and the consumption of turtle meat, eggs and blood was culturally entrenched (James \& Fournillier, 1993). However, at Grande Riviere consumption of turtle meat has become rare since the ecotourism operation began in 1992-1993 (Harrison, 2007). The beaches are managed by the forestry department in collaboration with local tour guiding and tourism community organizations. During the turtle laying and hatching season, between 18.00 and 06.00 , access to the beach is prohibited without the purchase of a permit, and visitors must be accompanied by an authorized guide or forestry official. The authorized guides are all from the village (Onwuka, 2004). The commitment of local people has been a key factor allowing the relative success of this initiative, as similar schemes have failed elsewhere in Trinidad (James \& Fournillier, 1993). 
Legislation for conservation includes an annual 6-month hunting ban for all game species, and a few species, including the pawi, benefit from year-round protection. In October 2004 Matura National Park was created adjacent to the village, and declared an Environmentally Sensitive Area.

There have also been education campaigns for conservation and advertisements and features on turtles, pawi and other wildlife in the national and local media (De-Light \& Thomas, 2005). The Forestry Division has organized various educational activities, often in schools. Prior to 2005 the last education campaign about the pawi was in 1997-1998 but in July 2005 a new poster was unveiled to mark the start of a new long-term education campaign for the pawi. The effect of these efforts on local attitudes and behaviours has not been monitored.

\section{Methods}

The survey was carried out in May-July 2005 using a complementary combination of Rapid Rural Appraisal (RRA) and questionnaire-based interviews. These methods collected both qualitative and quantitative data on perceptions of natural resources and their conservation, and allowed questionnaire design to be informed by the context of local life.

RRA is useful for collecting socio-economic data in a structured yet flexible way (Chambers, 1992). Techniques vary but emphasize visual approaches that promote community participation (Kapila \& Lyon, 1994). In this study it was used to understand the general context of village life, as well as perceptions and use of, and attitudes to, local natural resources. A men's group, a women's group, a mixed group and a children's group (each of 3-6 members) separately discussed similar issues, with some repetition of exercises between groups to validate findings. Subjects discussed included a village history timeline, land types and uses, natural resource uses, natural resource seasonality, food sources, livelihood ranking and wildlife conservation.

A questionnaire was developed from the information collected in the RRA. It was designed to collect information on knowledge, use and attitudes towards local natural resources, and household socio-economic attributes. A pilot questionnaire was administered at a similar rural village to test the comprehension, phrasing, sensitivity and length of the questionnaire, and to ensure interviewer approach was clear, non-leading and consistent. Trinidad is English speaking but a Trinidadian research assistant was used to ensure there were no problems from accent or cultural differences. A mixture of closed and open questions was used, with opportunity for discussion. Open responses were used where potential answers were diverse, to avoid biasing or limiting responses, and the information was later categorized for analysis.

Knowledge of local species was assessed by asking respondents to recognize and then name eight local species pictured in colour on laminated card, with one point awarded for recognition and another for the correct local name of each species, with a maximum score of 16 . Awareness of whether different types of conservation action had been applied locally for turtles and pawi was used to assess conservation knowledge.

Perceptions of conservation problems were elicited by open questions asking which plants or animals (if any) the respondent thought were threatened, and why, and what the biggest threat to local wildlife was. Support, or otherwise, for local conservation actions was elicited using a fivepoint Likert scale (Babbie, 2005) as were opinions on the amount of effort Trinidad should put into conservation.

Open questions were used to understand wild plants and animals eaten by the respondents, how these foods were obtained, favourite wild foods and why they were eaten. Other uses of wild species were also probed. A preference for wild meat versus domestic meat was indicated using a five-point Likert scale, and the frequency of wild meat consumption was elicited by open questions. If hunting was carried out by household members, this was recorded together with the reasons.

Personal data on the respondent and their household were recorded, including occupation, age, gender and educational status. A wealth indicator was the presence/ absence of 14 household attributes (such as a sewing machine, television or piped water) chosen from the 2000 census data as representative of a wide range of variation in household incomes (Government of Trinidad \& Tobago, 2001). A mark was awarded for each attribute present in the household, to a maximum of 14 .

The questionnaire survey sampled 52 households, nearly half the village. A random sampling method was used, with unavailable households revisited three times, to create a representative sample.

SPSS v. 11 (SPSS, Chicago, USA) was used for all statistical analysis (SPSS, 2001). Parametric tests were used where possible, using suitably transformed data where necessary. General Linear Model ANOVAs (GLM) were used for multivariate analysis and $\chi^{2}$ tests were used for count data. All statistical tests were two-tailed with a critical $\mathrm{P}$ of 0.05 .

\section{Results}

Socio-economic characteristics and the role of resource use

The age of respondents was $15-82$, although comparison with census data revealed a slight bias to those aged over 60 $\left(\chi^{2}=10.97, \mathrm{df}=3, \mathrm{P}<0.05\right)$. There was no gender bias. The majority of villagers had always lived in the village, although some had spent some time living in a town, and others had immigrated from elsewhere in Trinidad \& Tobago. The majority 
of respondents $(n=26)$ had received some form of post-primary education, although nearly as many had attended only primary school $(n=24)$. Only two respondents had any higher level of education. Spearman's rank tests revealed younger people were more likely to achieve higher levels of education $\left(r_{s}=-0.679\right.$, $\mathrm{df}=51, \mathrm{P}<0.001)$ and wealth was positively linked with education $\left(\mathrm{r}_{\mathrm{s}}=0.349, \mathrm{df}=51, \mathrm{P}<0.01\right)$ and increasing age $\left(r_{s}=0.349, d f=51, P<0.05\right)$.

Retirees were the single largest group (27\%) but other substantial groups were housewives, the unemployed and hotel workers. Manual labour jobs, farming and fishing were also common occupations. Many respondents had secondary jobs such as small-scale agriculture or tour guiding. RRA discussion indicated that obtaining work in a hotel was desirable because it was non-manual labour but less attractive than jobs that gave more reliable high pay (such as working on the road). Jobs in fishing, hunting, tour guiding and forestry were undesirable, as they were parttime and low-income. Even though multiple occupations were typically pursued within a household, wealth scores varied significantly with the primary occupation of respondents: the highest scoring primary occupation was manual labour (10.5 \pm SE 1.93), whilst running a small business scored the lowest $(2.5 \pm \mathrm{SE} 0.707)$. Intermediate scores were associated with a primary occupation of tour guiding (7.00 \pm SE 2.35) or hotel work (7.43 \pm SE 4.40).

Villagers had a wide variety of uses for their surrounding natural resources, whether wild, semi-wild or cultivated land. Although RRA indicated that private agricultural land was considered the most important land type (for the produce provided to householders and for sale), forests, rivers and sea were also highly rated. Several uses of natural resources were cited during the survey: wild vegetables and meats $(n=50)$, bush (herbal) medicine $(n=42)$, craft materials and hunting $(n=11)$, and timber $(n=2)$. RRA studies with children revealed a huge amount of knowledge of local species fished and hunted but hunting was not a sensitive subject for any class of respondent. Bush medicine was an especially popular topic, with some plants grown in backyards, and many people, especially women, listing several plants used and preferring to use medicinal herbs before seeking medical advice to treat minor ailments such as coughs, colds or menstrual complaints.

The range of knowledge scores obtained (6-16) showed substantial variation in respondents' ability to recognize and name local species. Multivariate analysis indicated that hunting and education were positively linked to higher levels of knowledge (Table 1).

\section{Awareness and attitudes towards turtles and pawi}

Comparison of perceptions of turtles and pawi indicated the additional effect of ecotourism on awareness and attitudes over that of other conservation activities. The higher visibility of turtles would reasonably cause greater recognition but not greater knowledge and concern for turtle conservation activities.

When asked if they knew of any threatened species, many more named the turtle $(n=23)$ than the next largest category, which was the pawi $(n=14)$. In addition, when asked what species or conservation issues required more attention, conserving the pawi was not mentioned but four respondents thought turtle conservation should be the main priority (issues relating to hunting and education were most often mentioned). Awareness of initiatives for conservation was also greater for turtles than for pawi (Table 2). Although many people were aware of education campaigns for pawi, the efforts for turtles were better recalled: recollections of pawi education were typically limited to broadcasts on radio and a tentative suggestion of activities for schoolchildren.

In the knowledge test significantly more respondents could recognize the turtle than the pawi $\left(\chi^{2}=4.88, \mathrm{df}=1\right.$, $\mathrm{P}<0.05$; Table 3 ), probably because the turtle is more often seen. Of those recognizing the animals, the proportion naming pawi was higher than for any other animal, including turtles and relatively common species such as agouti Dasyprocta fulignosa. In addition, those naming pawi were more likely to have a higher knowledge score (score computed excluding points for pawi, Mann-Whitney $U_{42,20}, Z=3.381, \mathrm{P}<0.001$ ), which suggests that knowledge of pawi may be derived from education programmes rather than direct observation.

\section{Effect of tourism benefits on attitudes and awareness}

There were two indicators of direct benefits received from ecotourism: one or more members of a household working as a tour guide $(n=15)$ or in a hotel $(n=19$, of which 9 also had a tour guide). Respondents from households with either of these indicators had significantly better knowledge than other households (Mann-Whitney $U_{27,25}, Z=-2.671$, $\mathrm{P}<0.01)$ and were also more likely to cite turtles as a threatened species $\left(\chi^{2}=4.854, \mathrm{df}=1, \mathrm{P}<0.05\right)$. When discussing local conservation of the pawi and turtles these households had substantially better awareness of local

TABLE 1 General Linear Model of the socio-economic attributes affecting knowledge score (log-transformed). Education categories are reduced to a binary variable, grouped according to presence or absence of post-primary level education. Significant predictors were selected in a stepwise manner, from gender, wealth, education, age, and hunting. Interactions were not tested due to the small sample size. Adjusted $R^{2}=0.286, F=11.2$, $\mathrm{df}=2, \mathrm{P}<0.001$.

\begin{tabular}{lllll}
\hline & df & Coefficient & F & $P$ \\
\hline Intercept & 1 & 0.458 & 517 & $<0.001$ \\
Education & 1 & 0.150 & 7.61 & $<0.01$ \\
Hunting & 1 & 0.169 & 9.04 & $<0.01$ \\
\hline
\end{tabular}


TABLE 2 The distribution of answers concerning awareness of the presence or absence of efforts to conserve pawi and turtles locally. Correct answers are: a protected area exists for the turtles but not for the pawi; a hunting ban applies year-round to pawi and to leatherback turtles and seasonally to other turtles (thus answers of seasonal bans for pawi and for leatherback turtles were scored as partially correct); education activities have been carried out for both leatherback turtles and pawi; a local ecotourism operation exists for turtles but not for pawi. Responses 'pawi' and 'all birds' were treated as one category for comparison with turtle score.

\begin{tabular}{|c|c|c|c|c|}
\hline Have there been... & Response $^{\star}$ & Pawi & Turtles & Difference? \\
\hline \multirow[t]{2}{*}{...protected areas? } & Correct & 47 & 44 & \multirow[t]{2}{*}{$\chi^{2}=0.791, \mathrm{df}=1, \mathrm{P} \geq 0.05$} \\
\hline & Incorrect & 5 & 8 & \\
\hline \multirow[t]{3}{*}{...hunting bans? } & Correct & 46 & 37 & \multirow{3}{*}{$\chi^{2}=9.71, \mathrm{df}=2, \mathrm{P}<0.01$} \\
\hline & Partial & 2 & 13 & \\
\hline & Incorrect & 4 & 2 & \\
\hline \multirow[t]{3}{*}{...education activities? } & Correct & 30 & 44 & \multirow[t]{3}{*}{$\chi^{2}=9.65, \mathrm{df}=2, \mathrm{P}<0.01$} \\
\hline & Incorrect & 21 & 7 & \\
\hline & $\mathrm{DK}$ & 1 & 1 & \\
\hline \multirow[t]{3}{*}{...ecotourism activities? } & Correct & pawi 28 , all birds 16 & 51 & \multirow[t]{3}{*}{$\chi^{2}=6.18, \mathrm{df}=2, \mathrm{P}<0.05$} \\
\hline & Incorrect & 5 & 1 & \\
\hline & $\mathrm{DK}$ & 3 & 0 & \\
\hline
\end{tabular}

${ }^{*}$ DK, don't know; Partial, partially correct

conservation measures and current activities. For example, unlike other respondents they all knew that there were no protected areas for pawi.

There was no effect of tourism benefits on support for local conservation or ecotourism initiatives, probably because community support for conservation was already very high (Fig. 1). Similarly, 51 of the 52 respondents supported ecotourism in the village, with the remaining respondent giving partial support.

Respondents from tour-guide or hotel-worker households were not biased by gender, age, education, occupation or wealth score (retirees were excluded to avoid bias in occupation and age associations).

\section{Perceptions and behaviours}

The activity of hunting and wild meat consumption indicated whether conservation awareness and attitudes were reflected in behaviours. Across the community there is a widespread perception that hunting is a significant threat to wild animals. When asked to think of threatened species there was a clear bias to those animals later identified as sources of wild meat (Table 4), and when informally discussing why those species were named the most frequent

TABLE 3 The number of respondents out of 52 recognizing and correctly naming pawi, leatherback turtle and agouti (selected as a comparator as it is locally common but is not the subject of any conservation or awareness campaigns). The names accepted as correct were local but specific rather than generic (e.g. 'leatherback turtle' not 'turtle').

\begin{tabular}{lcll}
\hline & Pawi & Turtle & Agouti \\
\hline Number recognizing & 45 & 51 & 51 \\
Number correctly naming & 42 & 41 & 37 \\
Proportion correctly naming & 0.93 & 0.80 & 0.73 \\
\hline
\end{tabular}

reason was hunting. Similarly, over half of respondents $(\mathrm{n}=32)$ named hunting as the biggest threat to wildlife in general (Fig. 2). Binary logistic regression indicated wealth was the only socio-economic attribute to predict wild meat consumption in the household (Nagelkerke Pseudo $\left.\mathrm{R}^{2}=0.246, \mathrm{df}=1, \mathrm{P}<0.05\right)$ and hunting in the household (Nagelkerke Pseudo $\mathrm{R}^{2}=0.194, \mathrm{df}=1, \mathrm{P}<0.05$ ), both with a positive relationship.

Hunting was a common and accepted pastime: about one third of households $(n=17)$ contained one or more hunters (usually male). Hunting was typically done at the weekend but would also be done opportunistically. The popularity of hunting is reflected by the reasons given for hunting: sport and/or cultural reasons were the motivation for the majority of hunting households (69\%). However, the high price of wild meat and its popularity (see below) suggest that hunting may significantly contribute to the livelihoods of a few.

Most survey respondents ate wild meat $(n=44)$, with their most frequently eaten and favourite wild meats similar to those rated important for hunting. There was a strong preference for wild over domestic meat (50/52 preferred wild meat), although not everyone was able to access or afford it and most respondents did not eat it often, usually less than once per month. Its popularity may be partially due to its scarcity: 'difference' and 'rarity' were commonly cited reasons for preference (Fig. 3). Popularity is reflected in price: for example, manicou Didelphis marsupialis meat can fetch up to USD $18 \mathrm{~kg}^{-1}$ (the same quantity of chicken meat costs c. USD 1). RRA groups and the household surveys indicated that pawi meat was not considered a particular prize for hunters nor a desirable meat to eat but it would probably be caught if encountered whilst hunters were looking for other prey. Discussion about wild meat indicated that price had drastically increased in the 


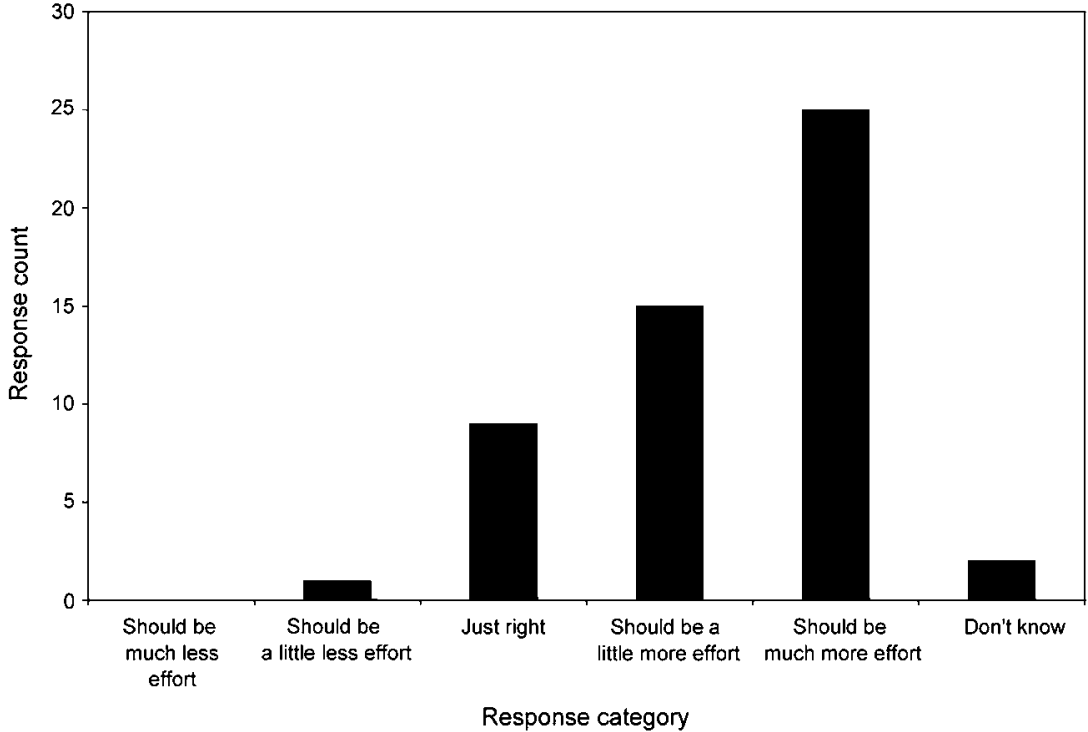

FIG. 1 Responses given to the question 'Is Trinidad putting the right amount of effort into conserving its plants and animals?' $(\mathrm{n}=52$; responses selected from 5-point Likert scale, or 'don't know' option). last 10 years and was now very high. Several respondents noted that the price increase could be linked to an increasing rarity of wild meat species.

\section{Discussion}

\section{Ecotourism affects awareness and attitudes to conservation}

Turtle-based ecotourism has had a pervasive effect on perceptions of wildlife and its conservation in Grande Riviere: local households generally have a greater awareness of turtle conservation than of pawi conservation even though both are found locally and both have been subjects of education and awareness campaigns. Receipt of direct benefits from ecotourism, through involvement in hotel work and related industries, seems to increase awareness of wildlife conservation issues further. Although some local commitment to turtle conservation preceded tourism, it is probable that tourism has widened and consolidated support for conservation throughout the community. In the words of a local tour guide, there is recognition of the "goose that lays the golden eggs, not just the eggs".

This study is also unusual in finding positive attitudes to tourism and conservation throughout the community. This may occur because Grande Riviere is not a large

TABLE 4 Species mentioned as threatened by questionnaire respondents. Up to three animals or plants were given by each respondent.

\begin{tabular}{|c|c|c|c|c|}
\hline Local category & Local name & Latin name & Response count & Source of wild meat \\
\hline \multirow[t]{11}{*}{ Wild animals } & Pawi & Pipile pipile & 14 & * \\
\hline & Iguana & Iguana iguana & 12 & * \\
\hline & All hunted & & 4 & * \\
\hline & Deer & Mazama americana & 2 & * \\
\hline & Agouti & Dasyprocta leporina & 1 & * \\
\hline & Butterflies & & 1 & \\
\hline & Manicou & Didelphis marsupialis & 1 & * \\
\hline & Most animals & & 1 & \\
\hline & Seed finch & Oryzoborus spp. & 1 & \\
\hline & Wild dog & Eira barbara & 1 & \\
\hline & Wild hog & Pecari tajacu & 1 & * \\
\hline \multirow[t]{4}{*}{ Turtles } & General & & 14 & \\
\hline & Leatherback & Dermochelys coriacea & 7 & \\
\hline & Leatherback \& hawksbill & D. coriacea \& Eretmochelys imbricata & 1 & \\
\hline & Leatherback elsewhere & D. coriacea & 1 & \\
\hline \multirow[t]{2}{*}{ Aquatic animal } & Fish \& crabs & & 2 & \\
\hline & Manatee & Trichechus spp. & 1 & \\
\hline \multirow[t]{2}{*}{ Plants \& trees } & Trees (aggregated) & & 4 & \\
\hline & Lots of plants & & 1 & \\
\hline Domestic animals & Hogs \& cattle & Sus domestica \& Bos taurus & 1 & \\
\hline
\end{tabular}

${ }^{\star}$ Identified as a source of wild meat by Rapid Rural Appraisal. 


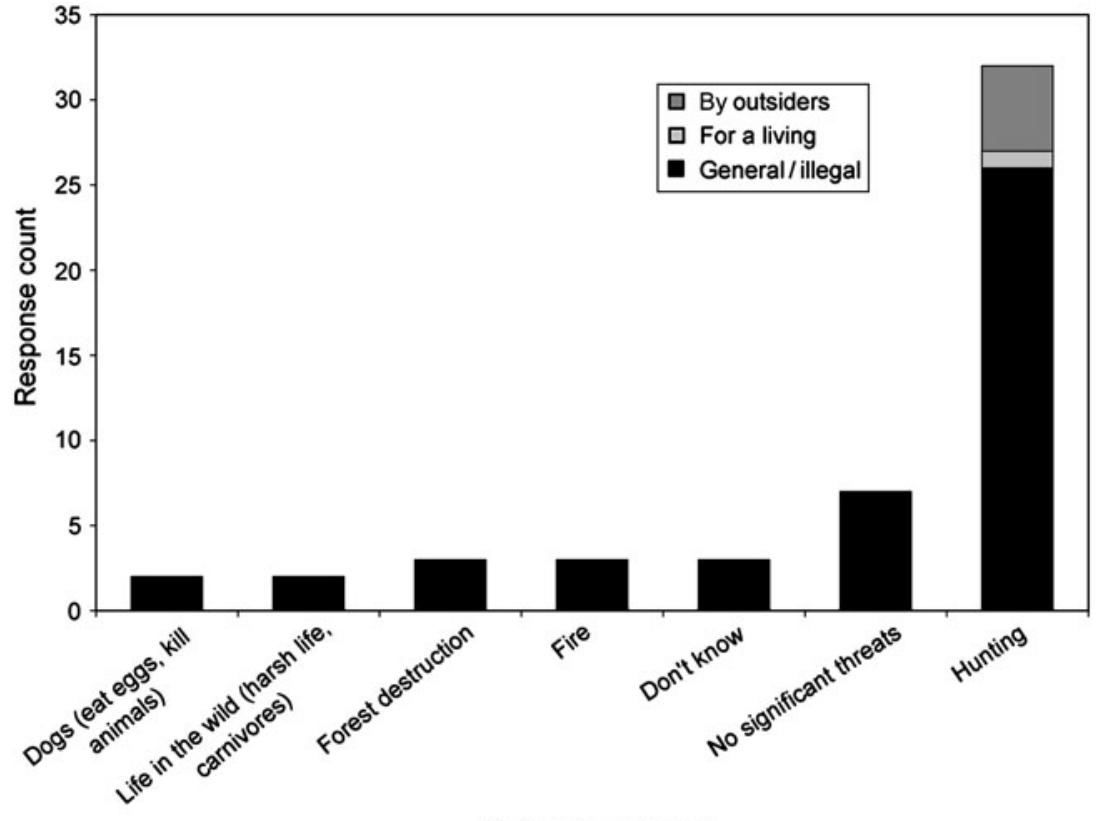

FIG. 2 Responses to question 'What do you think is the biggest threat to wildlife in this area?' $(\mathrm{n}=52)$. community and, although ecotourism does not involve every household in the village, it is likely that everyone is aware of the ecotourism operation and the actual or potential benefit for themselves, family or friends. Other studies have shown that community benefits and the hope of personal benefits can generate positive attitudes to a project even when present benefits are not distributed to all (Alexander, 2000). Other studies of ecotourism often do not find this appreciation of conservation. For example, Walpole \& Goodwin (2001) found that direct receipt of tourism benefits at Komodo National Park was linked with positive attitudes to tourism but not to support for conservation.

Those associated with tourism in Grande Riviere have better awareness of conservation than other inhabitants. It seems likely, therefore, that involvement in ecotourism is somehow predisposing people to learn more about local wildlife conservation in general, not just about turtles. It is possible that those involved in tourism had better preexisting knowledge of wildlife, although discussions with the community suggested this was unlikely for the majority of those involved. The mechanism of learning is unclear: there may be some learning directly from tourists and from following the tourists' example (the demonstration effect), because hotels are small and sufficiently friendly that staff and visitors interact (Dogan, 1989). Individuals may also learn from knowledgeable members of their community, especially tour guides, and may be predisposed to pay more attention to any formal education and awareness campaigns on the topic. Ecotourism's potential effect on awareness and attitudes is valuable because this is often not achieved through public education alone, or from the

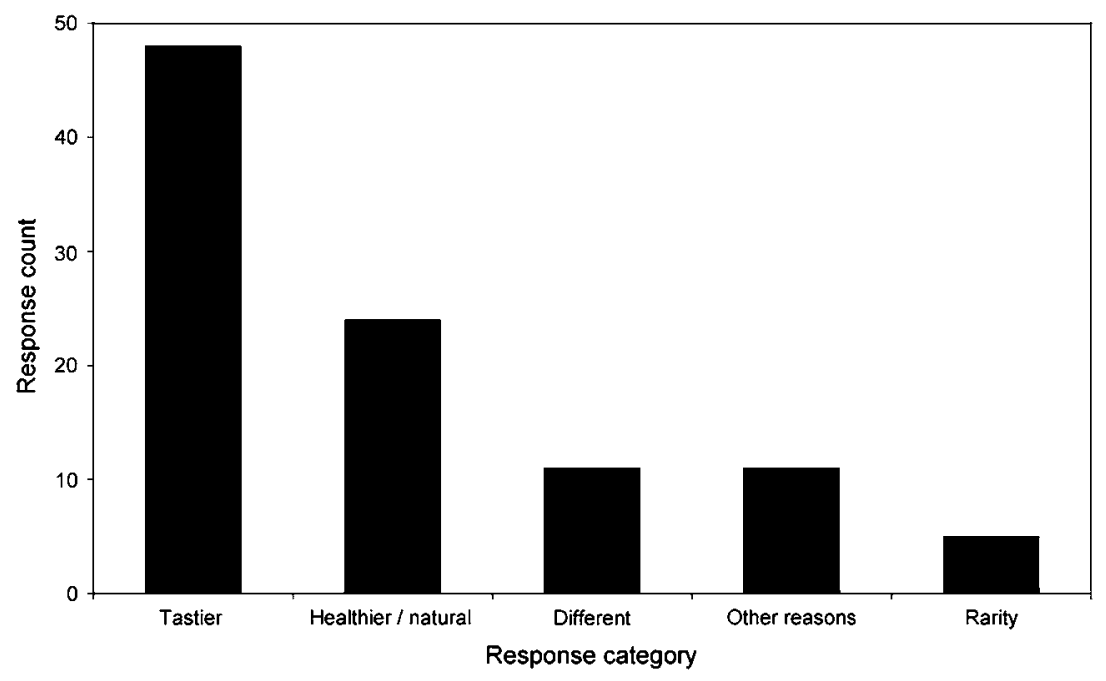

FIG. 3 The reasons given for preferring wild meat in response to the open question 'Why do you eat wild meat?' (sum of responses $>52$ as up to two reasons were allowed per respondent). 
receipt of benefits from Integrated Conservation and Development Projects (Struhsaker et al., 2005).

The past education and awareness campaigns for conservation may have influenced awareness (for example more of those recognizing pawi were able to name it than the more conspicuous turtle). However, if these campaigns are used in future, there must be a greater consideration of how they can affect personal behavioural change.

In this study a higher education status is linked with a greater knowledge of local species. Formal education is often found to predict awareness and attitudes of nature (Rauwald \& Moore, 2002), perhaps because it enables greater access to, and engagement with, information and awareness campaigns. Respondents from hunting households also have a higher knowledge score, probably because this facilitates more frequent direct experience with local natural features. Any future initiatives for conservation may require especial adjustment to ensure impact on other less knowledgeable sectors of society.

\section{Does changing awareness and attitudes}

matter for conservation?

Hunting is widely perceived as a threat to wildlife but this does not appear to influence behaviour, for wild meat consumption is widespread and hunting is a popular pastime. Sometimes subsistence needs constrain behaviours, regardless of attitudes (Marcus, 2001) but in this case hunting is driven by preference not necessity. Rarity can be a reason for preferring, rather than avoiding, wild meats. This type of disconnect has been noted in other community-based conservation programmes: Holmes (2003) found that positive attitudes towards Katavi National Park were not necessarily linked to a corresponding behavioural change of reduced fuelwood extraction, and a review of Integrated Conservation and Development Projects (Brooks et al., 2006) found predictors of attitudinal change to be separate from those of behavioural change. Psychological studies indicate that attitudes are related to behaviours through a complex relationship mediated by other factors (Ajzen, 2005) and thus care must be taken when eliciting and interpreting them. If positive attitudes do not translate into pro-conservation actions, then they are ultimately irrelevant to conservation goals.

These research findings were distributed to Grande Riviere community groups, academia and Trinidad's Environmental Management Authority. In 2007 this research was taken into account in a workshop held at Grande Riviere to plan conservation interventions for both pawi and turtles (Cooper \& Cooper, 2007). However, it remains to be seen if behaviours can be changed to support conservation: monitoring enthusiasm for hunting and wild-meat consumption will be valuable for determining the extent, if any, of behavioural change.

\section{Conclusions}

It is encouraging that ecotourism has the potential to influence awareness and attitudes to nature positively, and not just in those directly benefiting from it. Attitude change is often the only tool available to conservationists when approaches such as regulation are ineffective. At Grande Riviere ecotourism may therefore be a useful tool for pawi conservation if community involvement is maintained. However, to ensure that attitudes are translated into behaviour there is also a need for emphasis on personal behavioural change. The practice of hunting clearly illustrates that perception and concern for conservation problems may not be linked to behaviour. Studies of awareness and attitudes towards conservation issues must be aware of the potential mismatch with conservation behaviours.

\section{Acknowledgements}

We thank the UK's Natural Environment Research Council and the World Pheasant Association for support. The assistance of the University of the West Indies and many people in Trinidad made this study possible, especially the assistance of Kerrie Naranjit, Alesha Naranjit, and Srishti Mohais. We are most grateful to all those in Grande Riviere who took part in the study but especial thanks are due to Len Peters, Nicholas Alexander and Kevin Muhammad. We thank Drs David Harrison and Agnes Kiss for their comments on this paper.

\section{References}

Adams, W.M., Aveling, R., Brockington, D., Dickson, B., Elliott, J., Hutton, J. et al. (2004) Biodiversity conservation and the eradication of poverty. Science, 306, 1146-1149.

Adams, W.M. \& Infield, M. (2003) Who is on the gorilla's payroll? Claims on tourist revenue from a Ugandan National Park. World Development, 31, 177-190.

Ajzen, I. (2005) Attitudes, Personality and Behaviour. Open University Press, Maidenhead, UK.

Alexander, S.E. (2000) Resident attitudes towards conservation and black howler monkeys in Belize: the Community Baboon Sanctuary. Environmental Conservation, 27, 341-350.

Allendorf, T., Swe, K.K., Oo, T., Htut, Y., Aung, M., Aung, M. et al. (2006) Community attitudes toward three protected areas in Upper Myanmar (Burma). Environmental Conservation, 33, 344352.

B A в BIE, E.R. (2005) The Basics of Social Research. Thomson Wadsworth, London, UK.

BeEdell, J. \& Rehman, T. (200o) Using social-psychology models to understand farmers' conservation behaviour. Journal of Rural Studies, 16, 117-127.

Bookbinder, M.P., Dinerstein, E., Rijal, A., Cauley, H. \& RAJOURIA, A. (1998) Ecotourism's support of biodiversity conservation. Conservation Biology, 12, 1399-1404.

B rooks, D.M. (1999) Pipile as a protein source to rural hunters. In Biology and Conservation of the Piping-Guans (Pipile). Publication of the Cracid Specialist Group, No. 1 (eds D.M. Brooks, 
A. Begazo \& F. Olmos), pp. 43-50. Cracid Specialist Group, IUCN, Houston, USA.

Brooks, J.S., Franzen, M.A., Holmes, C.M., Grote, M.N. \& Mulder, M.B. (2006) Testing hypotheses for the success of different conservation strategies. Conservation Biology, 20, 1528-1538.

Brossard, D., Lewenstein, B. \& Bonney, R. (2005) Scientific knowledge and attitude change: the impact of a citizen science project. International Journal of Science Education, 27, 1099-1121.

Cater, E. \& Goodall, B. (1997) The need for sustainable tourism. In The Earthscan Reader in Sustainable Tourism (ed. L. France), pp. 85-89. Earthscan, London, UK.

Chambers, R. (1992) Rural Appraisal: Rapid, Relaxed and Participatory. Institute for Development Studies, Brighton, UK.

Cooper, J.E. \& Cooper, M. (2007) Conservation workshop held in Grande Riviere. UWI Today, 11 February 2007. Http://sta.uwi.edu/ uwiToday/2007/February/conserv.asp [accessed 28 August 2007].

CREP (2002) Caribbean Regional Environmental Programme. CREP, Christ Church, Barbados.

De-Light, D. \& Thomas, P. (2005) The Rough Guide to Trinidad and Tobago. Rough Guides, London, UK.

Dogan, H.Z. (1989) Forms of adjustment: socio-cultural impacts of tourism. Annals of Tourism Research, 16, 216-236.

GADD, M.E. (2005) Conservation outside of parks: attitudes of local people in Laikipia, Kenya. Environmental Conservation, 32, 50-63.

Government of Trinidad \& Tobago (2001) Central Statistical Office, Ministry of Planning and Development, Government of Trinidad and Tobago, Port of Spain, Trinidad.

Harrison, D. (2007) Cocoa, conservation and tourism, Grande Riviere, Trinidad. Annals of Tourism Research, 34, 919-942.

Hayes, F.E. (2002) Current Research Projects. Status, Ecology and Behaviour of the Endangered Trinidad Piping-Guan (Pipile pipile). $\mathrm{Http} / /$ www.geocities.com/floyd_hayes/research_piping-guan [accessed 20 August 2007].

Holmes, C.M. (2003) The influence of protected area outreach on conservation attitudes and resource use patterns: a case study from western Tanzania. Oryx, 37, 305-315.

IUCN (2008) 2008 IUCN Red List of Threatened Species. IUCN, Gland, Switzerland. Http://www.iucnredlist.org [accessed 12 March 2009].

James, C. \& Fournillier, K. (1993) Marine Turtle Management in North-East Trinidad. A Successful Community Based Approach Towards Endangered Species Conservation. CANARI with Wildlife Section, St Croix, US Virgin Islands.

James, C. \& Hislop, G. (1998) Status and Conservation of Two Cracid Species, the Pawi or Trinidad Piping-Guan (Pipile pipile) and the Cocrico (Ortalis ruficauda) in Trinidad and Tobago. Forestry Division, Port of Spain, Trinidad.

LORIMER, J. (2009) International conservation volunteering from the UK: what does it contribute? Oryx, 43, 352-360.

Kapila, S. \& Lyon, F. (1994) People-Oriented Research. Expedition Advisory Centre, Royal Geographical Society, London, UK.

Kideghesho, J.R., Roskaft, E. \& Kaltenborn, B.P. (2007) Factors influencing conservation attitudes of local people in Western Serengeti, Tanzania. Biodiversity and Conservation, 16, 2213-2230.

Kiss, A. (2004) Is community-based ecotourism a good use of biodiversity conservation funds? Trends in Ecology \& Evolution, 19, 232-237.

KRUGER, O. (2005) The role of ecotourism in conservation: panacea or Pandora's box? Biodiversity and Conservation, 14, 579-600.

MAIBACH, E. (1993) Social marketing for the environment: using information campaigns to promote environmental awareness and behaviour change. Health Promotion International, 8, 209-224.

MARCUS, R.R. (2001) Seeing the forest for the trees: integrated conservation and development projects and local perceptions of conservation in Madagascar. Human Ecology, 29, 381-397.
Menta, J.N. \& Kellert, S.R. (1998) Local attitudes towards community-based conservation policy and programmes in Nepal: a case study in the Makalu-Barun Conservation Area. Environmental Conservation, 25, 320-333.

ONWUKA, O. (2004) Kill nothing but time, take nothing but memories. MA thesis, University of Amsterdam, Amsterdam, The Netherlands.

Rauwald, K.S. \& Moore, C.F. (2002) Environmental attitudes as predictors of policy support across three countries. Environment and Behaviour, 34, 709-739.

S Aunders, C.D., Brook, A.T. \& Myers, O.E. (2006) Using psychology to save biodiversity and human well-being. Conservation Biology, 20, 702-705.

Schultz, P.W. (2001) The structure of environmental concern: concern for self, other people, and the biosphere. Journal of Environmental Psychology, 21, 327-339.

SeKercioglu, C.H. (2002) Impacts of birdwatching on human and avian communities. Environmental Conservation, 29, 282-289.

SPiteri, A. \& NePAL, S.K. (2006) Incentive-based conservation programs in developing countries: a review of some key issues and suggestions for improvements. Environmental Management, $37,1-14$.

Struhsaker, T.T., Struhsaker, P.J. \& Siex, K.S. (2005) Conserving Africa's rainforests: problems in protected areas and possible solutions. Biological Conservation, 123, 45-54.

The International Ecotourism Society (2005) Ecotourism Fact Sheet. The International Ecotourism Society, Washington, DC, USA.

UNWTO (2006) Poverty Alleviation Through Tourism-A Compilation of Good Practices. UN World Tourism Organization, Madrid, Spain.

Walpole, M.J. \& Goodwin, H.J. (2001) Local attitudes towards conservation and tourism around Komodo National Park, Indonesia. Environmental Conservation, 28, 160-166.

Walpole, M.J. \& Leader-Williams, N. (2002) Tourism and flagship species in conservation. Biodiversity and Conservation, $11,543-547$.

Weaver, D.B. (1998) Ecotourism in the Less Developed World. CAB International, Wallingford, UK.

Wood, M. (2002) Ecotourism: Principles, Practices and Policies for Sustainability. The International Ecotourism Society \& United Nations Environment Division, Paris, France.

Yu, D.W., Hendrickson, T. \& Castillo, A. (1997) Ecotourism and conservation in Amazonian Peru: short-term and long-term challenges. Environmental Conservation, 24, 130-138.

\section{Biographical sketches}

KERRY WAYLEN is concerned with improving conservation outcomes in developing countries, using both socio-economic and biological knowledge. She is currently evaluating community-based conservation projects. Philip McGowan is Director of the World Pheasant Association. He is concerned with ensuring that no species of Galliformes go extinct and balancing the needs of all 300 species of Galliformes with those of the communities that live alongside them. The Pawi Study Group is a multidisciplinary group established in 2004 with the mission to increase knowledge and understanding of the endemic and endangered Trinidad piping-guan while promoting conservation of the bird and its habitat through awareness-raising and public support. Its members come from a variety of zoological and environmental organizations, and the University of the West Indies, Trinidad. E.J. Milner-Gulland's research lies at the interface of human and ecological systems, with a particular focus on the conservation of harvested species. Her group's website is http://www.iccs.org.uk 